\title{
Knoevenagel Condensation of Aromatic Aldehydes with Ethyl 4-Chloro-3-oxobutanoate in Ionic Liquids
}

\author{
Bruno R. S. de Paula, ${ }^{a}$ Dávila S. Zampieri, ${ }^{a}$ Julio Zukerman-Schpector, ${ }^{b}$ \\ Edward R. T. Tiekink, ${ }^{c}$ José Augusto R. Rodrigues ${ }^{a}$ and Paulo J. S. Moran*,a \\ anstitute of Chemistry, University of Campinas, CP 6154, 13083-970 Campinas-SP, Brazil \\ ${ }^{\mathrm{b}}$ Department of Chemistry, Federal University of São Carlos, 13565-905 São Carlos-SP, Brazil \\ ${ }^{c}$ Department of Chemistry, University of Malaya, 50603 Kuala Lampur, Malaysia
}

\begin{abstract}
Condensações de Knoevenagel de aldeídos aromáticos com 4-cloro-3-oxobutanoato de etila catalisadas por morfolina/ácido acético foram conduzidas em líquidos iônicos para fornecerem 2-cloroacetil-3-arilpropenoatos de etila em 44 a $84 \%$ de rendimentos após 0,5 a $2 \mathrm{~h}$ à temperatura ambiente $\left(25-28^{\circ} \mathrm{C}\right)$. Estas condições representam um protocolo mais verde para a condensação de Knoevenagel do que aquelas realizadas com refluxo de benzeno e tolueno, utilizados como solventes. Aldeídos aromáticos contendo grupos arila, 4-clorofenila, 4-metoxifenila, 2-tiofuranila, 2-furanila, fenila e 3,4-metilenodioxifenila apresentaram razões diastereoméricas $(E) /(Z)$ de 56/44 a 85/15. A estrutura do isômero-( $E$ ) do 2-cloroacetil-3-(3',4'-metilenodioxifenil)propenoato de etila foi determinada por difração de raio $X$, e uma metodologia inequívoca da análise estrutural- $(E) /(Z)$ por RMN de ${ }^{13} \mathrm{C}$ (ressonância magnética nuclear) é apresentada.
\end{abstract}

Knoevenagel condensations of aromatic aldehydes with ethyl 4-chloro-3-oxobutanoate catalyzed by morpholine/acetic acid were carried out in ionic liquids to give ethyl 2-chloroacetyl3 -arylpropenoates in $44-84 \%$ yield after 0.5 to $2 \mathrm{~h}$ at room temperature $\left(25-28^{\circ} \mathrm{C}\right)$. These conditions represent a greener protocol for the Knoevenagel condensation than those using refluxing benzene or toluene as solvent. Aromatic aldehydes having aryl groups 4-chlorophenyl, 4-methoxyphenyl, 2-thiofuranyl, 2-furanyl, phenyl and 3,4-methylenedioxyphenyl gave $(E) /(Z)$ diastereomeric ratios of products from $56 / 44$ to $85 / 15$. The two isomers of each compound were separately isolated and characterized. The structure of the (E)-isomer of ethyl 2-chloroacetyl-3-(3',4' methylenedioxyphenyl) propenoate was determined by X-ray crystallography and an unequivocal methodology of $(E) /(Z)$-structural analysis by ${ }^{13} \mathrm{C}$ NMR (nuclear magnetic resonance) is presented.

Keywords: Knoevenagel condensation, ethyl 4-chloro-3-oxobutanoate, ionic liquid, ethyl (E/Z)-2-chloroacetyl-3-arylpropenoate

\section{Introduction}

In our studies of the bioreduction of $\alpha$-haloketones and enones, ${ }^{1}$ one of our objectives is the asymmetric synthesis of chiral halogenated $\beta$-hydroxyesters and related compounds by means of reduction of halogenated $\beta$-ketoesters mediated by yeasts and bacteria. In particular, the bioreduction of ethyl 4-chloroacetoacetate derivatives bearing $\mathrm{C}=\mathrm{C}$ double bonds at the $\mathrm{C}-2$ position is a potential approach to a tandem formation of two contiguous stereogenic centers in a highly functionalized molecule.

*e-mail: moran@iqm.unicamp.br
A set of desired compounds for these studies are ethyl 2-chloroacetyl-3-arylpropenoates, envisaged to be prepared by means of a Knoevenagel condensation between ethyl 4-chloroacetoacetate and aromatic aldehydes. However, reports of this kind of condensation involving halogenated ketoesters are scarce at best, and the most reproducible method employs benzene as solvent and refluxing in a Dean-Stark to remove water from the reaction medium. ${ }^{2}$ Although the authors successfully obtained the product of the condensation between ethyl 4-chloroacetoacetate and benzaldehyde in up to $58 \%$ yield, the use of considerable amounts of a hazardous organic solvent, high temperature and rather long reaction time are undesirable for a reaction that would be carried out 
routinely. It is interesting to notice that, to this day, these conditions are still rather common in the literature for the Knoevenagel condensation involving several aldehydes and active methylene compounds. ${ }^{3}$

Due to the above inconveniences, we envisaged the use of ionic liquids as a potential alternative to the conventional solvents. ${ }^{4}$ In recent years, ionic liquids have been the subject of considerable interest as an efficient solvent, ${ }^{5}$ and even as catalys $^{6}{ }^{6}$ for the Knoevenagel condensation. Furthermore, we have recently reported a study of the methylenation of several carbonyl compounds in ionic liquids, using paraformaldehyde as the methylene source and morpholine/ acetic acid as catalyst. ${ }^{7}$

In the present work, we present the results of the Knoevenagel condensation between ethyl 4-chloroacetoacetate $\mathbf{1}$ and aromatic aldehydes $\mathbf{2 a - f}$ catalyzed by morpholine/acetic acid carried out in ionic liquids in presence of molecular sieves at room temperature.

\section{Results and Discussion}

In preliminary experiments to determine the best reaction conditions, it was undertaken reactions varying the concentration of ethyl 4-chloroacetoacetate $\mathbf{1}$ and aromatic aldehydes $\mathbf{2 a}$, the amount of catalyst added and the nature of the ionic liquid. Since in a previous work, ${ }^{7}$ the best methylenation results were achieved using [bmim $\left.\left(\mathrm{PF}_{6}\right)\right]$ (1-butyl-3-methylimidazolium hexafluorophosphate) and [bmim $\left.\left(\mathrm{NTf}_{2}\right)\right]$ (1-butyl3-methylimidazolium bis(trifluoromethanesulfonyl) imide), they were the chosen ionic liquids in this work as the potential solvents for the condensation of $\mathbf{1}$ with 2a to afford 3a. The reaction conditions, as well as the reaction yields, are presented in Table 1. Thus, the ionic liquid $\left[\operatorname{bmim}\left(\mathrm{NTf}_{2}\right)\right]$ was the solvent of choice for the condensation and $2 \mathrm{~mol} \mathrm{~L}^{-1}$ concentration of $\mathbf{2 a}$ and $10 \mathrm{~mol} \%$ of the catalyst (entry 5) were chosen as best reaction conditions.

Once established the best reaction conditions, we were prompted to investigate whether the ionic liquid could be reused several times. Thus, four consecutive experiments of ionic liquid reuse in the Knoevenagel condensation were performed using entry 5 conditions stated in Table 1. To avoid manipulation issues that may arise when using smaller amounts of the ionic liquid, as well as to verify if this condensation could be carried out in a larger scale, we were prompted to perform the reaction in a $10 \mathrm{mmol}$ scale instead of $2 \mathrm{mmol}$. The yields for these experiments are shown in Figure 1. When working in a larger scale, even in the first reaction, the reagent had not been completely consumed in $1 \mathrm{~h}$, and the reaction had to be carried out
Table 1. Reaction yields for the Knoevenagel condensation between ethyl 4-chloroacetoacetate (1) and benzaldehyde (2a) in ionic liquids ${ }^{\mathrm{a}}$

\begin{tabular}{|c|c|c|c|c|}
\hline & & & 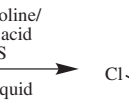 & \\
\hline entry & $\begin{array}{l}\text { Ionic } \\
\text { liquid }\end{array}$ & $\begin{array}{c}\mathbf{2 a} \\
\text { Concentration } \\
\left(\mathrm{mol} \mathrm{L}^{-1}\right)^{\mathrm{b}}\end{array}$ & $\begin{array}{c}\text { Catalyst }^{\mathrm{c}} / \\
\mathrm{mol} \%\end{array}$ & $\begin{array}{c}3 \mathbf{a} \\
\text { Yield }^{\mathrm{d}} / \\
\%\end{array}$ \\
\hline 1 & {$\left[\operatorname{bmim}\left(\mathrm{PF}_{6}\right)\right]$} & 1.0 & 10 & 52 \\
\hline 2 & & 1.0 & 20 & 60 \\
\hline 3 & & 2.0 & 10 & 66 \\
\hline 4 & & 2.0 & 20 & 61 \\
\hline 5 & {$\left[\operatorname{bmim}\left(\mathrm{NTf}_{2}\right)\right]$} & 2.0 & 10 & 77 \\
\hline 6 & & 2.0 & 20 & 55 \\
\hline
\end{tabular}

a Reactions were carried out on a $2 \mathrm{mmol}$ scale for $1 \mathrm{~h}$ at $25-28{ }^{\circ} \mathrm{C}$; ${ }^{\mathrm{b}} 1.2$ equivalent of 1 was used; ${ }^{\mathrm{m}}$ morpholine/acetic acid (1:1); ${ }^{\mathrm{d}}$ sum of the yields of the $E$ and $Z$ isomers, after column chromatography.

for $2 \mathrm{~h}$ instead. Moreover, from the initial amount of [bmim $\left.\left(\mathrm{NTf}_{2}\right)\right](7.14 \mathrm{~g})$, a mass of $5.57 \mathrm{~g}$ of the ionic liquid (78\% of the initial amount) was recovered after four cycles of use.

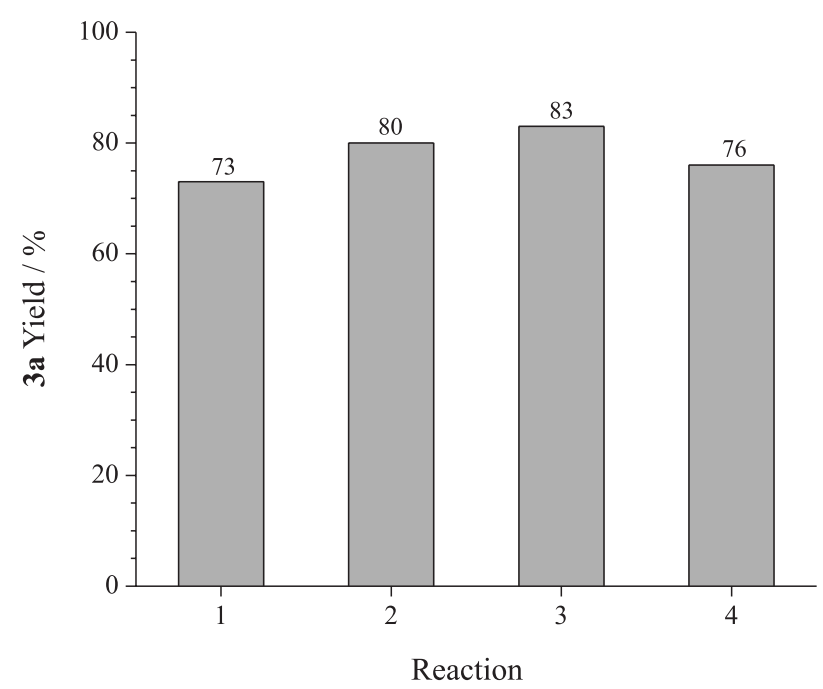

Figure 1. Reaction yields for the condensation between $1(12 \mathrm{mmol})$ and 2a (10 mmol) over four reuses of ionic liquid cycles (reaction carried out on a $5 \mathrm{~mL}$ of [bmin $\left.\left(\mathrm{NTf}_{2}\right)\right]$, morpholine $(1 \mathrm{mmol})$, acetic acid $(1 \mathrm{mmol})$ and molecular sieves $(1.8 \mathrm{~g})$ at $\left.25-28^{\circ} \mathrm{C}\right)$.

Furthermore, to compare the reaction in [bmim $\left.\left(\mathrm{NTf}_{2}\right)\right]$ with the traditional protocol, reactions were also performed in refluxing benzene and toluene, using a Dean-Stark to remove water from the reaction medium. The reaction conditions and yields are summarized in Table 2. Although the reaction in benzene also furnishes $\mathbf{3 a}$ in a high yield, the use of benzene (which is a known carcinogen), high 
temperature and extended reaction time are conditions that render the reaction less attractive. On the other hand, an attempt to substitute benzene for toluene was unfortunately unsuccessful, as the reaction yield decreased considerably. This may be due to the higher reflux temperature, which can be responsible for degradation of reagents and/or products. Nevertheless, the pronounced ionic liquid effect has been suggested by Pinto et al. ${ }^{8}$ and de Oliveira et al. ${ }^{9}$ as a powerful combination capable of co-promoting the formation and stabilization of different types of ionic intermediates ${ }^{10}$ during this kind of condensation catalyzed by morpholine/acetic acid.

Table 2. Reaction conditions and yields for the Knoevenagel condensation between ethyl 4-chloroacetoacetate (1) and benzaldehyde (2a) ${ }^{\mathrm{a}}$

\begin{tabular}{lccc}
\hline Solvent & $\begin{array}{c}\text { Temperature / } \\
{ }^{\circ} \mathrm{C}\end{array}$ & $\begin{array}{c}\text { Reaction time / } \\
\mathrm{h}\end{array}$ & $\begin{array}{c}\text { Yield }^{\mathrm{b}} / \\
\%\end{array}$ \\
\hline$[$ bmim(NTf $)]$ & $25-28$ & 2.0 & 73 \\
$2^{\text {nd }}$ use & & & 80 \\
$3^{\text {rd }}$ use & & & 83 \\
$4^{\text {th }}$ use & & & 76 \\
Benzene & 80 & 4.0 & 75 \\
Toluene & 110 & 4.0 & 35 \\
\hline
\end{tabular}

${ }^{\mathrm{a}}$ Reactions were carried out on a $10 \mathrm{mmol} \mathrm{scale}$; ${ }^{\mathrm{b}}$ sum of the yields of the $E$ and $Z$ isomers, after column chromatography.

To extend this protocol to other aromatic aldehydes, reactions were performed with aldehydes $\mathbf{2 b}-\mathbf{f}$. The yields for each reaction performed in accordance with experimental condition stated in entry 5 of Table 1 , as well as the $(E / Z)$-isomers ratio, are collected in Table 3.

The $(E / Z)$-configurations of the obtained products were assigned based on the $\mathrm{X}$-ray crystallographic analysis of the major isomer in product $3 \mathbf{d}^{11}$ and ${ }^{13} \mathrm{C}$ NMR spectra data. From X-ray crystallography (Figure 2), the $(E)$-configuration was established for the major $\mathbf{3 d}$ isomer. The analysis also shows the chloroacetyl residue to be approximately orthogonal to the remaining molecule (torsion angle $\left.=-87.87(18)^{\circ}\right)$.

In order to analyze the two isomeric structures of $\mathbf{3 d}$ in greater detail, density functional theory calculations were performed with the DFT/B3LYP/6-31G++(d,p) basis set. ${ }^{12}$ The calculations show that the $(E)$-isomer is $0.125 \mathrm{kcal} \mathrm{mol}^{-1}$ more stable than $(Z)$-isomer. While the chloroacetyl residue is out of molecule plane in $(E)$-structure, in agreement with the structure determined by X-ray crystallography by stark contrast in the (Z)-isomer, it is the ester residue that now lies approximately perpendicular to the remaining molecular plane (Figure 3).

When the major isomer (i.e., with the (E)-configuration) of product $\mathbf{3 d}$ was subjected to the magnetic field in ${ }^{13} \mathrm{CNMR}$
Table 3. Reaction time, yield and diastereomeric ratio for the Knoevenagel condensation between ethyl 4-chloroacetoacetate and aromatic aldehydes ${ }^{\mathrm{a}}$

2d

${ }^{\text {aReactions were carried out on a } 2 \mathrm{mmol} \text { scale at room temperature }}$

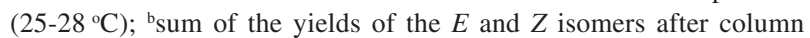
chromatography; ${ }^{\mathrm{c}}$ determined by ${ }^{1} \mathrm{H}$ NMR of the crude mixture.

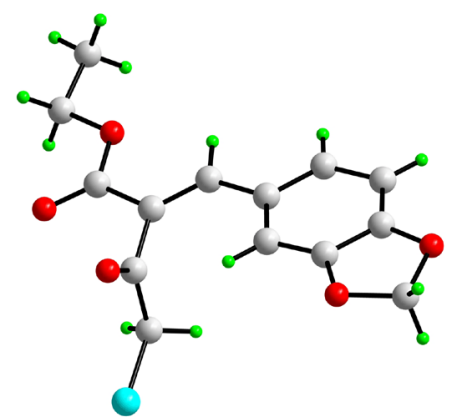

Figure 2. The molecular structure of $\mathbf{3 d}$ determined by X-ray crystallography.

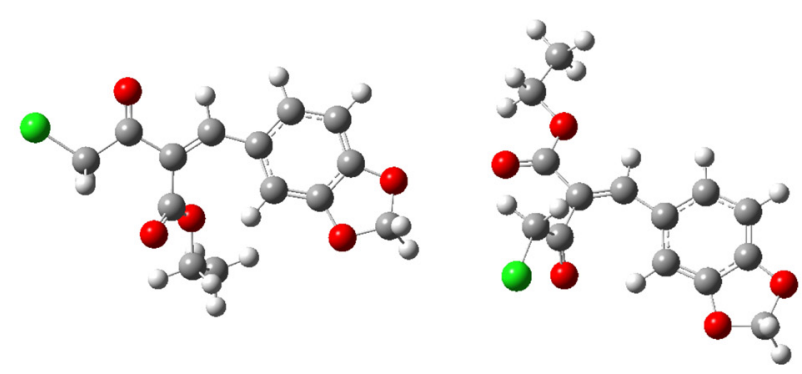

Figure 3. Minimum energy calculated molecular $(Z)$ - and $(E)$-structures of 3d with DFT/B3LYP/6-31G++(d,p).

analysis, the carbon atom of the $\mathrm{CH}_{2} \mathrm{Cl}$ group appears at $49.2 \mathrm{ppm}$ while the corresponding carbon atom in the (Z)-isomer appears at $46.2 \mathrm{ppm}$. In addition, the carbon atom 
Table 4. ${ }^{13} \mathrm{C}$ NMR chemical shifts for the $-\underline{\mathrm{C}} \mathrm{H}_{2} \mathrm{Cl}, \underline{\mathrm{C}}=\mathrm{O}$ keto and $-\underline{\mathrm{C}}(=\mathrm{O})$ OEt carbons for the major and minor isomers $(\mathbf{3 a}-\mathbf{f})$

\begin{tabular}{|c|c|c|c|c|c|c|}
\hline \multirow{2}{*}{ Product } & \multicolumn{3}{|c|}{ Major isomer $(E), \delta / \mathrm{ppm}$} & \multicolumn{3}{|c|}{ Minor isomer $(Z), \delta / \mathrm{ppm}$} \\
\hline & $\underline{\mathrm{CH}}_{2} \mathrm{Cl}$ & $\underline{\mathrm{C}}=\mathrm{O}$ keto & $-\underline{\mathrm{C}}(=\mathrm{O}) \mathrm{OEt}$ & $\underline{\mathrm{CH}}_{2} \mathrm{Cl}$ & $\underline{\mathrm{C}}=\mathrm{O}$ keto & $-\underline{\mathrm{C}}(=\mathrm{O}) \mathrm{OEt}$ \\
\hline $3 \mathbf{a}$ & 49.2 & 196.6 & 163.8 & 46.0 & 188.3 & 167.0 \\
\hline $3 \mathbf{b}$ & 49.0 & 196.5 & 163.6 & 46.2 & 188.2 & 166.7 \\
\hline $3 \mathbf{c}$ & 49.3 & 197.0 & 164.2 & 46.2 & 188.3 & 167.5 \\
\hline 3d & 49.2 & 196.9 & 164.0 & 46.2 & 188.2 & 167.3 \\
\hline $3 \mathbf{e}$ & 49.1 & 195.3 & 164.0 & 46.3 & 187.8 & 166.6 \\
\hline $3 f$ & 49.1 & 195.4 & 164.5 & 47.0 & 189.2 & 166.1 \\
\hline
\end{tabular}

of carbonyl group in the $(E)$-isomer appears at $196.9 \mathrm{ppm}$ while corresponding carbon atom in the $(Z)$-isomer appears at $188.2 \mathrm{ppm}$. On the other hand, the carbon atom of carboxylic group of the molecule with $(Z)$-configuration $\mathbf{3 d}$ appears at $167.3 \mathrm{ppm}$ while corresponding carbon atom in the $(E)$-isomer appears at $164.0 \mathrm{ppm}$. A close analysis of the structures readily rationalizes the downfield shifts observed in the ${ }^{13} \mathrm{C}$ NMR spectra, i.e., of the carboxylic carbon of the $(Z)$-isomer and, the carbonyl and $\mathrm{CH}_{2} \mathrm{Cl}$ carbons of the $(E)$-isomer owing to their proximity and coplanarity with the aromatic moiety. The analysis of ${ }^{13} \mathrm{C}$ NMR spectra data of $\mathbf{3 a}-\mathbf{c}$ and $\mathbf{3 e - f}$, and comparison to that of $\mathbf{3 d}$, focusing on that anisotropic effect, allowed the assignment of the configurations in each case (Table 4).

\section{Conclusions}

In summary, it was demonstrated that the Knoevenagel condensation of ethyl 4-chloroacetoacetate with aldehydes 1a-f may be accomplished in the ionic liquid [bmim $\left.\left(\mathrm{NTf}_{2}\right)\right]$ as the solvent, and $10 \mathrm{~mol} \%$ of morpholine/acetic acid as catalyst, to give the corresponding propenoates 3a-f in good yields, and with the $(E)$-isomer generally dominant. The reaction time of 0.5 to $2 \mathrm{~h}$ at room temperature and the reuse of the ionic liquid make it a suitable protocol as an alternative to the use of benzene or toluene at reflux temperature. The $(E)$ - and $(Z)-\mathbf{3 a}-\mathbf{f}$ were isolated, characterized and an unequivocal methodology of $(E) /(Z)$-structural analysis by ${ }^{13} \mathrm{C}$ NMR is presented.

\section{Experimental}

All reagents were obtained from commercial sources. Benzaldehyde, $p$-anysaldehyde, piperonal and ethyl 4-chloroacetoacetate were purchased from Aldrich. Furfural was purchased from Fisher, 4-chlorobenzaldehyde and morpholine were purchased from Merck, 2-formylthiophene was purchased from Avocado, and glacial acetic acid was purchased from Synth. Benzaldehyde, $p$-anysaldehyde, furfural, 2-formylthiophene and ethyl 4-chloroacetoacetate were distilled before use. All the other reagents were used as received.

Ionic liquids were prepared following a literature procedure, ${ }^{13}$ using 1-butyl-3-methylimidazolium trifluoromethanesulfonate (Aldrich) and potassium hexafluorophosphate (Aldrich) or lithium bis(trifluoromethanesulfonimide) (Aldrich).

Diethyl ether, benzene and toluene were purchased from Synth. Before use, both benzene and toluene were dried over sodium overnight, then distilled and stored over sodium. Diethyl ether was used as received. Intact $4 \AA$ molecular sieves (Aldrich) were employed.

Thin-layer chromatography (TLC) analyses were performed with precoated aluminum sheets (silica gel 60 Merck), and flash column chromatography was carried out on silica (200-400 mesh, Merck).

${ }^{1} \mathrm{H}$ NMR spectra were determined at $250 \mathrm{MHz}$ (Varian Gemini 250) or $500 \mathrm{MHz}$ (INOVA 500). ${ }^{13} \mathrm{C}$ NMR spectra were determined at $62.5 \mathrm{MHz}$ (Varian Gemini 250) or 125.7 MHz (INOVA 500). Chemical shifts are reported in ppm relative to tetramethylsilane (TMS, $\delta 0.00$ for ${ }^{1} \mathrm{H}$ ) in $\mathrm{CDCl}_{3}$.

GC-MS (gas chromatography-mass spectroscopy) analyses were obtained on an Agilent 6890 Series GC System and mass spectra were recorded with a Hewlett-Packard 5973 mass selective detector $(70 \mathrm{eV})$ using a HP-5MS fused silica capillary column (crosslinked $5 \%$ phenyl ethyl siloxane, $30 \mathrm{~m} \times 0.25 \mathrm{~m}$ ID $\times 0.25 \mu \mathrm{m}$ film thickness) and helium as a carrier gas $\left(1 \mathrm{~mL} \mathrm{~min}^{-1}\right)$. The split ratio was 1:50. The injector temperature was kept $270{ }^{\circ} \mathrm{C}$ and detector at $280{ }^{\circ} \mathrm{C}$. The column temperature was held at $60^{\circ} \mathrm{C}$ for $3 \mathrm{~min}$ and then increase to $280{ }^{\circ} \mathrm{C}$ at a rate of $20^{\circ} \mathrm{C} \mathrm{min}^{-1}$, and then kept constant for 2 min at $280^{\circ} \mathrm{C} .1 \mu \mathrm{L}$ of a compound solution $\left(1 \mathrm{mg} \mathrm{mL}^{-1}\right)$ in ethyl acetate was injected, and the retention times in minutes are reported for each compound.

IR spectra were recorded on a FTIR BOMEM MB-100 from Hartmann \& Braun. 
GC-HRMS (gas chromatography high-resolution mass spectrometry) analyses were performed on a GCT Premier (Waters) GC-MS/TOF (time-of-flight) using a HP5-MS column $(30 \mathrm{~m} \times 0.25 \mathrm{~mm}$ ID $\times 0.25 \mu \mathrm{m}$ film thickness $)$. The injector temperature was kept at $260^{\circ} \mathrm{C}$ and detector at $280{ }^{\circ} \mathrm{C}$. The column temperature was held at $100^{\circ} \mathrm{C}$ for $1 \mathrm{~min}$ and then increase to $280{ }^{\circ} \mathrm{C}$ at a rate of $10^{\circ} \mathrm{C} \mathrm{min}^{-1}$. $1 \mu \mathrm{L}$ of a compound solution $\left(1 \mathrm{mg} \mathrm{mL}^{-1}\right)$ in ethyl acetate was injected.

Melting points $(\mathrm{mp})$ were determined on a Gehaka PF1000 or on a Gehaka PF1500.

General procedure for the Knoevenagel condensation in ionic liquids

Morpholine (17.4 mg, $0.1 \mathrm{mmol}$ ), glacial acetic acid (12.0 mg, $0.2 \mathrm{mmol})$ and aldehyde $(2 \mathrm{mmol})$ were added to the ionic liquid $(1 \mathrm{~mL})$ in a $10 \mathrm{~mL}$ round-bottom flask. The mixture was stirred for $10 \mathrm{~min}$, then ethyl 4-chloroacetoacetate ( $395 \mathrm{mg}, 2.4 \mathrm{mmol}$ ) and 4 Å molecular sieves $(360 \mathrm{mg}$ ) were added, and the mixture was stirred at room temperature $\left(25-28{ }^{\circ} \mathrm{C}\right)$. After the reaction time, the products were extracted with diethyl ether $(3 \times 5 \mathrm{~mL})$, the ether was evaporated and the $(E)$ - and $(Z)$-product mixture was isolated by column chromatography on silica gel $(50 \mathrm{~g}$ of silica: $1 \mathrm{~g}$ of crude mixture) using hexane/ethyl acetate (95\%:5\%) as eluent. For characterization purposes, the $(E)$ - and $(Z)$-products were further separated from each other by column chromatography on silica gel ( $200 \mathrm{~g}$ of silica: $1 \mathrm{~g}$ of crude mixture) using hexane/ethyl acetate as eluent, ranging from pure hexane to $95 \%$ hexane:5\% ethyl acetate.

Procedure for the Knoevenagel condensation between ethyl 4-chloroacetoacetate and benzaldehyde in $\left[\operatorname{bmim}\left(\mathrm{NTf}_{2}\right)\right]$ recycle experiments

Morpholine ( $87 \mathrm{mg}, 1 \mathrm{mmol}$ ), glacial acetic acid (60 mg, $1 \mathrm{mmol}$ ) and benzaldehyde (1.06 g, $10 \mathrm{mmol})$ were added to $\left[\mathrm{bmim}\left(\mathrm{NTf}_{2}\right)\right](5 \mathrm{~mL})$ in a $25 \mathrm{~mL}$ round-bottom flask. The mixture was stirred for $10 \mathrm{~min}$, then ethyl 4-chloroacetoacetate $(1.97 \mathrm{~g}, 12 \mathrm{mmol})$ and $4 \AA$ molecular sieves $(1.80 \mathrm{~g})$ were added, and the mixture was stirred at room temperature $\left(25-28^{\circ} \mathrm{C}\right)$. The reaction was monitored by TLC, and after $2 \mathrm{~h}$, the products were extracted with diethyl ether $(4 \times 10 \mathrm{~mL})$. The ether was evaporated and the products were purified by column chromatography (on silica gel using hexane/ethyl acetate as solvent, ranging from pure hexane to $95 \%$ hexane:5\% ethyl acetate). The ionic liquid was washed with $10 \mathrm{~mL}$ of water, then transferred to another $25 \mathrm{~mL}$ round bottom flask with the aid of ethyl acetate $(4 \times 1 \mathrm{~mL})$. The solvent was evaporated under vacuum and the ionic liquid reloaded with the reagents, catalyst and molecular sieves for subsequent reaction.

After the fourth reaction, $5 \mathrm{~mL}$ of ethyl acetate was added to the ionic liquid, and the organic phase was washed with distilled water $(3 \times 5 \mathrm{~mL})$. The organic layer was filtered through a short basic alumina column (using ethyl acetate as the eluent), the solvent was evaporated and the ionic liquid was dried under reduced pressure.

Procedure for the Knoevenagel condensation between ethyl 4-chloroacetoacetate and benzaldehyde in benzene and toluene

Morpholine ( $87 \mathrm{mg}, 1 \mathrm{mmol}$ ), glacial acetic acid ( $60 \mathrm{mg}$, $1 \mathrm{mmol})$ and benzaldehyde $(1.06 \mathrm{~g}, 10 \mathrm{mmol})$ were added to benzene or toluene $(5 \mathrm{~mL})$ in a $25 \mathrm{~mL}$ round-bottom flask connected to a Dean-Stark apparatus. The mixture was stirred for $10 \mathrm{~min}$, and then ethyl 4-chloroacetoacetate (1.97 g, $12 \mathrm{mmol}$ ) was added to reaction mixture, which was brought to a reflux. The reaction was monitored by TLC, and after $4 \mathrm{~h}$, the reaction mixture was cooled, diluted with diethyl ether $(20 \mathrm{~mL})$ and washed with water $(2 \times 10 \mathrm{~mL})$. The solvents were evaporated, and the products were purified by column chromatography (on silica gel using hexane/ethyl acetate as solvent, ranging from pure hexane to $95 \%$ hexane:5\% ethyl acetate).

\section{Acknowledgements}

Conselho Nacional de Desenvolvimento Científico e Tecnológico (CNPq), Fundação de Amparo à Pesquisa do Estado de São Paulo (FAPESP) and the Ministry of Higher Education, Malaysia, High-Impact Research scheme (UM.C/HIR/MOHE/SC/12) to ERTT are gratefully acknowledged.

\section{Supplementary Information}

EI-MS, IR, ${ }^{1} \mathrm{H}$ NMR, ${ }^{13} \mathrm{C}$ NMR, EI-HRMS spectra and spectral data of all synthetized compounds are available free of charge at http://jbcs.sbq.org.br as PDF file.

\section{References}

1. Fardelone, L. C.; Rodrigues, J. A. R.; Moran, P. J. S.; Enzyme Res. 2011, 2011, ID 976368, DOI 10.4061/2011/976368; Zampieri, D. S.; Zampieri, L. A.; Rodrigues, J. A. R.; de Paula, B. R. S.; Moran, P. J. S.; J. Mol. Catal. B: Enzym. 2011, 72, 289. 
2. Surrey, A. R., Hammer, H. F., Suter, C. M.; J. Am. Chem. Soc. 1944, 66, 1933.

3. Huang, J.; Leboeuf, D.; Frontier, A. J.; J. Am. Chem. Soc. 2011, 133, 6307; Mori, K.; Ehara, K.; Kurihara, K.; Akiyama, T.; J. Am. Chem. Soc. 2011, 133, 6166; Alajarin, M.; Marin-Luna, M.; Vidal, A.; Adv. Synth. Catal. 2011, 353, 557; Xia, G.; Benmohamed, R.; Kim, J.; Arvanites, A. C.; Morimoto, R. I.; Ferrante, R. J.; Kirsch, D. R.; Silverman, R. B.; J. Med. Chem. 2011, 54, 2409.

4. Welton, T.; Chem. Rev. 1999, 2615; Chowdhury, S.; Mohan, R. S.; Scott, J. L.; Tetrahedron 2007, 63, 2363; Parvulescu, V. I.; Hardacre, C.; Chem. Rev. 2007, 107; Hallett, J. P.; Welton, T.; Chem. Rev. 2011, 3508.

5. Hu, Y.; Guan, Z.; He, Y.-H.; Louwagie, N.; Yao, M.-J.; J. Chem. Res. 2010, 22; Jiang T.; Han, B. X.; Curr. Org. Chem. 2009, 13, 1278; Tahmassebi, D.; Wilson L. J. A.; Kieser, J. M.; Synth. Commun. 2009, 39, 2605; Valizadeh, H.; Vaghefi, S.; Synth. Commun. 2009, 39, 1666; Zlotin, S. G.; Kryshtal, G. V.; Zhdankina, G. M.; Ignatenko, A. V.; Bugart, Y. V.; Saloutin V. I.; Chupakhin, O. N.; Russ. J. Org. Chem. 2010, 46, 468; Verdia, P.; Santamarta, F.; Tojo, E.; Molecules 2011, 16, 4379; Forbes, D. C.; Law, A. M.; Morrison, D. W.; Tetrahedron Lett. 2006, 47, 1699.

6. Yue, C.; Mao, A.; Wei, Y.; Lu, M.; Catal. Commun. 2008, 9, 1571; Valizadeh, H.; Gholipour, H.; Synth. Commun. 2010, 40, 1477; Le, Z.-G.; Zhong, T.; Xie, Z.-B.; Lu, X.-X.; Cao, X.; Synth. Commun. 2010, 40, 2525; Ying, A.-G.; Wang, L.-M.; Wang, L.-L.; Chen, X.-Z.; Ye, W.-D.; J. Chem. Res. 2010, 30; Xu, D.-Z.; Liu, Y.; Shi, S.; Wang, Y.; Green Chem. 2010, 12, 514; Zhou, Z.; Yuan, J.; Yang, R.; Synth. Commun. 2009, 39, 2001.

7. Vale, J. A.; Zancheta, D. F.; Moran, P. J. S.; Rodrigues, J. A. R.; Synlett 2009, 75.

8. Pinto, A. C.; Lapi, A. A. M.; da Silva, B. V.; Bastos, R. S.; Dupont, J.; Neto, B. A. D.; Tetrahedron Lett. 2008, 49, 5639.

9. de Oliveira, V. M.; de Jesus, R. S.; Gomes, A. F.; Gozzo, F. C.; Umpierre, A. P.; Suarez, P. A. Z.; Rubin, J. C.; Neto, B. A. D.; ChemCatChem 2011, 3, 1911.
10. Milagre, C. D. F.; Milagre, H. M. S.; Santos, L. S.; Lopes, M. L. A.; Moran, P. J. S.; Eberlin, M. N.; Rodrigues, J. A. R.; J. Mass Spectrom. 2007, 42, 1287.

11. Zukerman-Schpector, J.; Salim, S. N. A.; Moran, P. J. S.; de Paula, B. R. S.; Rodrigues, J. A. R.; Tiekink, E. R. T.; Acta Cryst. 2011, E67, o1044.

12. Frisch, M. J.; Trucks, G. W.; Schlegel, H. B.; Scuseria, G. E.; Robb, M. A.; Cheeseman, J. R.; Montgomery, J. A.; Vreven, T.; Kudin, K. N.; Burant, J. C.; Millam, J. M.; Iyengar, S. S.; Tomasi, J.; Barone, V.; Mennucci, B.; Cossi, M.; Scalmani, G.; Rega, N.; Petersson, G. A.; Nakatsuji, H.; Hada, M.; Ehara, M.; Toyota, K.; Fukuda, R.; Hasegawa, J.; Ishida, M.; Nakajima, T.; Honda, Y.; Kitao, O.; Nakai, H.; Klene, M.; Li, X.; Knox, J. E.; Hratchian, H. P.; Cross, J. B.; Bakken, V.; Adamo, C.; Jaramillo, J.; Gomperts, R.; Stratmann, R. E.; Yazyev, O.; Austin, A. J.; Cammi, R.; Pomelli, C.; Ochterski, J. W.; Ayala, P. Y.; Morokuma, K.; Voth, G. A.; Salvador, P.; Dannenberg, J. J.; Zakrzewski, V. G.; Dapprich, S.; Daniels, A. D.; Strain, M. C.; Farkas, O.; Malick, D. K.; Rabuck, A. D.; Raghavachari, K.; Foresman, J. B.; Ortiz, J. V.; Cui, Q.; Baboul, A. G.; Clifford, S.; Cioslowski, J.; Stefanov, B. B.; Liu, G.; Liashenko, A.; Piskorz, P.; Komaromi, I.; Martin, R. L.; Fox, D. J.; Keith, T.; Al-Laham, M. A.; Peng, C. Y.; Nanayakkara, A.; Challacombe, M.; Gill, P. M. W.; Johnson, B.; Chen, W.; Wong, M. W.; Gonzalez, C.; Pople, J. A.; Gaussian 03, Revision A.1; Gaussian, Inc., Pittsburgh: PA, 2003.

13. Cassol, C. C.; Ebeling, G.; Ferrera, B.; Dupont, J.; Adv. Synth. Catal. 2006, 348, 243.

Submitted: December 15, 2011

Published online: March 29, 2012

FAPESP has sponsored the publication of this article. 